\section{HONOURS, AWARDS, APPOINTMENTS}

Honorary membership of ADAPT

Restorative dentist Dr Howard Stean from Kew has

presented an honorary membership of ADAPT (Aesthetic

Dentistry and Professional Testing) to Dr Bernard Fialkoff a periodontist from Bayside in New York and the first American invited to join ADAPT. Dr Stean presented Dr Fialkoff with membership as Dr Stean opened his lecture on dental implants at the monthly Fialkoff Queens Dental Study Club in New York.

\section{Seven years of service}

Linda Erickson has received a gift from the President of the British Society of Prosthodontics (BSSPD) on behalf of the Council for her seven years of continual service as Administrator. Linda was presented with the gift at a recent BSSPD Roadshow at Newcastle Dental Hospital after announcing her retirement as Society Administrator.

UK's best dental practice

tooth+, a small private dental surgery in Stirling, has been named the UK's best dental practice at The Dentistry Awards 2011. The practice, set up by Dr Rachael Blyth in January 2010, won the title due to its customer-focused approach to dentistry.

\section{Keith Woods Memorial Prize}

NHS Lanarkshire's oral health team has won the Keith Woods Memorial Prize for a written submission on the oral health needs assessment of homeless people in Lanarkshire. The prize, organised by the British Association for the Study of Community Dentistry (BASCD), is awarded to BASCD members who produce a written submission of original research work or good practice in oral health needs assessment or dental epidemiology. Albert Yeung, NHS Lanarkshire consultant of Dental Public Health, received the award at the BASCD Presidential Scientific Meeting in London in November.

\section{Best Customer Service}

Total Orthodontics, a group of specialist orthodontic practices based in Sussex and Kent, was announced as the winner of the Best Customer Service category at the Sussex Business Awards 2011. Total Orthodontics is the largest provider of NHS orthodontic care in the South East and competed against a wide range of local and national businesses from the private sector.

\section{Most accessed paper}

UCL public health researchers Dr Cesar de Oliveira, Professor Richard Watt and Dr Mark Hamer have been awarded the most accessed British Medical Journal paper in 2010. Their paper on toothbrushing, inflammation and risk of cardiovascular disease (2010; 340: c2451) received a great deal of international media attention including an interview on the BBC Radio 4 Today programme.

\section{New BDTA President}

BDTA President Edward Attenborough handed over to incoming President for 2012-2013, Simon Tucker, at the BDTA's Midwinter Meeting in London in December. The next BDTA Annual Conference will take place on 21-23 June 2012 at the Runnymede-on-Thames hotel.

\section{MISSING IN MERSEYSIDE}

Paul John Morson, born 22

November 1979, was reported missing on 10 June 2011 having last been seen two days previously. A criminal investigation into his disappearance is now underway.

D/C Eddie Holmes of Stanley Road Police Station, Merseyside
Police, would like all dental professionals to check their records for the last year to confirm if anyone by the name of Paul John Morson has registered with them.

D/C Holmes can be contacted on 01517778622 or by emailing edward.j.holmes@merseyside. police.uk.

\title{
CLASS OF '71 HIT STRATFORD
}

Towards the end of 201130 members of the class of 1971 celebrated the 40th anniversary of their qualification from Birmingham Dental Hospital with a weekend away in Stratford-upon-Avon.

It was the group's first reunion for ten years and proved an enjoyable weekend culminating in a dinner at the Alveston Manor Hotel on the Saturday night. Many of the group are reaching the end of their careers or have recently retired and for some it was the first reunion they had attended since graduation.

'Everybody seemed to have a story to tell and many student photographs and memories of the Birmingham Dental Hopsital and its staff were swapped long into the night, said Laurie Jacobs, a dentist from Leicester. 'All branches of dentistry were represented and it was interesting to hear how everybody's careers had progressed over the years.'

The group hope to meet again in five years' time.

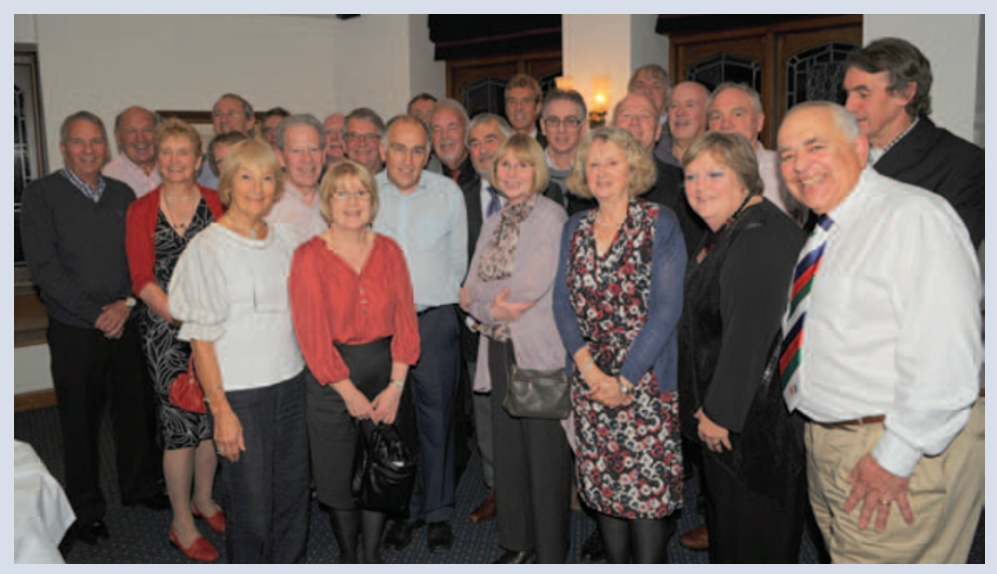

\section{AOG CELEBRATES 30 YEARS}

On 10 December 2011 the AOG held its esteemed Annual Ball at the Millennium Hotel in Mayfair, in honour of its 30th anniversary. The event celebrated the organisation's three decades as one of the UK's leading dental community groups.

Tickets for the event sold out in record time and attendees enjoyed an Indian feast and classical Indian music from Simran Ghalley and Kudos.

Since its incarnation all AOG activities have led to charitable contributions. As well as supporting a cleft lip and palate treatment centre that provides facilities for 500 villages, the AOG is involved in building a rehabilitation centre for disabled people in Musoma, Tanzania. At the Annual Ball President Dr Pomi Datta announced that the AOG was donating $£ 5,000$ to this particular cause.

For details of future events, visit www.aoguk.org. 